\title{
Nutrient production in pastures of Triticale BRS Saturno submitted to different levels of nitrogen in topdressing
}

\section{Produção de nutrientes em pastagens de Triticale BRS Saturno submetidas a diferentes doses de adubação nitrogenada em cobertura}

\author{
Gustavo Veiverberg Antunes ${ }^{1}$; Ione Maria Pereira Haygert-Velho'; Andiara Laíssa \\ Bernardi'; Carlos Zandoná Rupollo3; Gadriéli Cristina Gheno ${ }^{4}$; Gabriela Feiten \\ Gabbi'; Júlia Laize Bandeira Calgaro5; João Pedro Velho*
}

\section{Highlights}

Nutrient production in Triticale pasture was influenced by nitrogen topdressing.

$\mathrm{N}$ fertilization increased total carbohydrate deposition.

$\mathrm{N}$ fertilization increased neutral detergent fiber deposition and digestibility.

Protein degradability was significantly changed with higher $\mathrm{N}$ fertilization.

$\mathrm{N}$ fertilization in Triticale pastures changed the deposition of ether extract.

\begin{abstract}
Pastures are a primary source of feed for ruminants, which convert fibrous plants into nutritionally valuable foods for humans, such as meat and milk. However, it is important to understand the nutrient content of different fodder crops for ruminants and its effect on meat, milk, and milk products. We aimed to evaluate the effect of nitrogen fertilizer doses in topdressing on nutrient production in pastures of Triticale BRS Saturno. The experimental design was a randomized block with five replications. Descriptive statistics of yields per hectare were determined, and a simple linear regression was carried out at the level of $5 \%$ significance. The different nitrogen topdressing rates $\left(0,50\right.$, and $\left.100 \mathrm{~kg} \mathrm{~N} \mathrm{ha}^{-1}\right)$ influenced the production $(P<0.05)$ of

1 Undergraduate Course in Zootecnia, Universidade Federal de Santa Maria, UFSM, Campus de Palmeira das Missões, Palmeira das Missões, RS, Brazil. E-mail: gustavo.veiverberg@hotmail.com; andiarabernardi@gmail.com; gabrielagabbi@hotmail.com

2 Profs., Department of Zootechnics and Biological Sciences, UFSM, Campus de Palmeira das Missões, Palmeira das Missões, RS, Brazil. E-mail: ione.h.velho@ufsm.br; velhojp@ufsm.br

3 Prof., União Central de Educação Faem Faculdades, UCEFF Faculdades, Chapecó, SC, Brazil. E-mail: carlos@uceff.edu.br

${ }^{4}$ Graduate Student, Graduate Program in Animal Science, Universidade do Estado de Santa Catarina, UDESC, Lages, SC, Brazil. E-mail: gadrieligheno@hotmail.com

5 Graduate Student, Graduate Program in Agribusiness, UFSM, Campus de Palmeira das Missões, Palmeira das Missões, RS, Brazil. E-mail: julia_calgaro@hotmail.com

* Author for correspondence
\end{abstract}

Received: Oct. 23, 2020 - Approved: Dec. 22, 2020 
dry matter, total carbohydrates, neutral detergent fiber, acid detergent fiber, crude protein, soluble protein, insoluble protein in neutral and acid detergent, protein degradability, ether extract, linoleic and linolenic fatty acids, neutral detergent fiber digestibility after incubation for 24, 30, and $48 \mathrm{~h}$, and the neutral detergent fiber degradation rate. The different doses of nitrogen fertilizer in topdressing in the form of urea increased nutrient production in pastures of Triticale BRS Saturno, mainly in relation to total carbohydrates and neutral and acid detergent fiber. To a lesser extent, it also significantly interfered with the production of nitrogenous constituents and fatty acids.

Key words: Carbohydrates. Digestible NDF. Ether extract. Linolenic. Nitrogen. $X$ Triticosecale Wittmack.

\section{Resumo}

As pastagens são a principal fonte de alimentação dos ruminantes, que convertem as plantas fibrosas em alimentos nutricionalmente valiosos para os humanos, como carne e leite. No entanto, é importante compreender o teor de nutrientes de diferentes espécies forrageiras para ruminantes e seus efeitos na carne, leite e derivados lácteos. Objetivou-se avaliar os efeitos das doses de adubação nitrogenada em cobertura sobre a produção de nutrientes em pastagens de Triticale BRS Saturno. O delineamento experimental utilizado foi de blocos casualizados com cinco repetições. Os tratamentos aplicados foram doses de nitrogênio em cobertura $\left(0,50\right.$, e $\left.100 \mathrm{~kg} \mathrm{~N} \mathrm{ha}^{-1}\right)$, utilizando ureia comum. Foram calculadas as produções por hectare de cada nutriente da pastagem. Foram determinadas as estatísticas descritivas das produções por hectare e realizado estudo por regressão linear simples ao nível de 5\% de significância. As diferentes doses de nitrogênio em cobertura influenciaram as produções $(P<0,05)$ de: matéria seca, carboidratos totais, fibra em detergente neutro, fibra em detergente ácido, proteína bruta, proteína solúvel, proteína insolúvel em detergente neutro e ácido, a degradabilidade da proteína, extrato etéreo, ácidos graxos linoléico e linolênico, digestibilidade da fibra em detergente neutro com incubação por 24, 30, e 48h, e taxa de degradação da fibra em detergente neutro. As diferentes doses de adubação nitrogenada em cobertura na forma de ureia incrementam a produção de nutrientes em pastagens de Triticale BRS Saturno, principalmente sobre os carboidratos totais e a fibra em detergente neutro e ácido. Também interferem sobre a produção dos constituintes nitrogenados e ácidos graxos.

Palavras-chave: Carboidratos. Extrato etéreo. FDN digestível. Linolênico. Nitrogênio. $X$ Triticosecale Wittmack.

\section{Introduction}

Pastures are one of the main sources of feed and nutrition for ruminants because of their ability to digest fibrous materials, and the meat and milk from these ruminants can then be used to provide foods of high biological value for humans (Van Soest, 1994). Physiologically managed pastures provide important ecosystem services, as they simultaneously generate animal products and mitigate greenhouse gases (Oliveira et al., 2017; Savian et al., 2018).

Dual-purpose winter cereals (Avena sativa L.; Avena strigosa Schreb; Hordeum vulgare L.; Secale cereale; Triticum aestivum; $X$ Triticosecale Witt.) that allow the production of both pasture and grains during the same harvest cycle, have been used in several countries, including Australia (Sprague, Kirkegaard, Graham, Dove, \& Kelman, 2014; Sprague et al., 2018), Brazil (Meinerz et al., 
2012; Quatrin et al., 2017; Carvalho et al. 2018), China (Tian, Bell, Shen, \& Wish, 2012 Hu et al., 2019), and Italy (Giunta, Motzo, Virdis, \& Cabigliera, 2017; Giunta, Cadeddu, Mureddu, Virdis, \& Motzo, 2020), among many others. They are seen as a way to intensify production on rural properties and increase profitability (Ates et al., 2018) by increasing integrated agricultural production systems in the short term (Henz et al., 2016).

Although the growth of forage plants occurs exponentially (Thornley \& France, 2004), dual-purpose species management usually involves only one or two grazing or cutting events (Bortolini, Sandini, Carvalho, \& Moraes, 2004), to avoid harming grain production (Fontaneli et al., 2009; Santos, Fontaneli, Caierão, Spera, \& Vargas, 2011). Topdressing with nitrogen fertilizer is a quick and practical way to increase biomass production per hectare (Pembleton, Rawnsley, \& Burkitt, 2013; Skinner, 2013). However factors such as the thermal sum (Müller et al., 2009) and water availability also influence the production of dry matter per hectare (Zaka, Frak, Julier, Gastal, \& Louarn, 2016).

It is important to examine individual elements in the dry matter production in detail, in order to understand how each nutrient in the pasture can affect the dynamics of animal metabolism, based on their voluntary intake, and to decide which other ingredients, and in which quantities, should be part of the ruminant diet (Lanzas, Sniffen, Seo, Tedeschi, \& Fox, 2007; Tylutki et al., 2008). The synergies of carbohydrates and nitrogenous constituents for the production of microbial proteins affect the performance of ruminants (Bumbieris et al., 2011). The biofunctional nutrients (fatty acids) contained in pastures affect the composition of meat (Freitas et al., 2014; Lobato et al., 2014) and milk (Buccioni, Decandia, Minieri, Molle, \& Cabiddu, 2012; Liu et al., 2020). The production of nutrients in Triticale pastures is the result of the interaction of climatic conditions, represented mainly by the thermal sum and the physiological cycle of the plants (Coblentz, Akins, Kalscheur, Brink, \& Cavadini, 2018).

Thus, the objective of this study was to determine the production of dry matter, total carbohydrates, soluble, fibrous and non-fibrous carbohydrates, nitrogenous constituents, and lipid fractions of pastures of Triticale BRS Saturno subjected to different doses of nitrogen fertilization in topdressing.

\section{Material and Methods}

The present study was carried out in the experimental field area of the Laboratório de Bovinocultura of the Departamento de Zootecnia e Ciências Biológicas of the Palmeira das Missões, Campus of the Universidade Federal de Santa Maria. The soil in the experimental area is classified as a typical LATOSSOLO VERMELHO Distrófico, belonging to the Unidade de Mapeamento de Passo Fundo-RS (Streck et al., 2018). The climate according to the Köppen classification is a subtropical "Cfa" type with hot summers and well-distributed rainfall (Alvares, Stape, Sentelhas, Gonçalves, \& Sparovek, 2013). Table 1 shows the normal weather conditions between 1961 and 1990 and the weather conditions during the study, recorded by the Automatic Weather Station of Palmeira das Missões (longitude: 27055'10" S, latitude: $53^{\circ} 19^{\prime} 15^{\prime \prime} \mathrm{W}$, altitude: $\left.615 \mathrm{~m}\right)$, which is located approximately $200 \mathrm{~m}$ from the experiment site. 
Table 1

Normal climatological between 1961 and 1990 for Palmeira das Missões, State of Rio Grande do Sul and meteorological conditions during the experimental period

\begin{tabular}{|ccccc|}
\multirow{2}{*}{ Period } & \multicolumn{4}{c|}{ Meteorological conditions } \\
\cline { 2 - 5 } & \multicolumn{2}{c|}{ Normal climatological (1961-1990) } & \multicolumn{2}{c|}{ Experiment (2019) } \\
\cline { 2 - 5 } June & Average temperature $\left({ }^{\circ} \mathrm{C}\right)$ & Rainfall $(\mathrm{mm})$ & Average temperature $\left({ }^{\circ} \mathrm{C}\right)$ & Rainfall $(\mathrm{mm})$ \\
\hline 14-30 June 2019 & 13.5 & 123.3 & -- & -- \\
\hline July & -- & -- & 17.8 & 32.2 \\
\hline August & 13.3 & 143.0 & 13.1 & 85.4 \\
\hline 1-25 August 2019 & 14.4 & 196.0 & -- & -- \\
\hline Mean/Total & -- & -- & 13.3 & 29.6 \\
\hline & 13.7 & 462.3 & 14.7 & 147.2 \\
\hline
\end{tabular}

The results of the soil analysis were: $\mathrm{pH}$ in water $5.3 ; 2.0 \%$ organic matter; calcium 3.5 cmolc $\mathrm{dm}^{-3}$; magnesium $1.8 \mathrm{cmolc} \mathrm{dm}^{-3} ; 0.3$ cmolc $\mathrm{dm}^{-3}$ of aluminum; hydrogen + aluminum

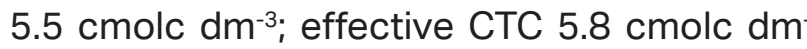
3; $5.2 \%$ aluminum saturation; base saturation 49.6\%; SMP index 5.8; sulfur $4.3 \mathrm{mg} \mathrm{dm}^{-3}$; phosphorus $8.3 \mathrm{mg} \mathrm{dm}^{-3}$; potassium $68 \mathrm{mg}$ $\mathrm{dm}^{-3}$; copper $1.91 \mathrm{mg} \mathrm{dm}^{-3}$; zinc $0.67 \mathrm{mg} \mathrm{dm}^{-3}$ and boron $0.3 \mathrm{mg} \mathrm{dm}^{-3}$. The base fertilization was calculated from the analysis carried out by the Laboratório de Análise de Solo of the Universidade Federal de Santa Maria, applying $350 \mathrm{~kg} \mathrm{ha}^{-1}$ of formulated fertilizer (NPK 05-2020).

The experimental design was a randomized block with five replications. The plots were $4 \mathrm{~m}$ wide by $8 \mathrm{~m}$ long and the spacing between lines was $0.17 \mathrm{~m}$. Sowing of Triticale (X Triticosecale Wittmack) BRS Saturno was carried out on June 14, 2019, with a sowing density of $150 \mathrm{~kg} \mathrm{ha}^{-1}$. The treatments applied were different nitrogen doses $(0,50$, and 100 $\mathrm{kg}$ of $\mathrm{N} \mathrm{ha}^{-1}$ ), using common urea. In the $50 \mathrm{~kg}$ $\mathrm{N}$ ha ${ }^{-1}$ treatment, the entire dose was applied on July 16,2019 , while in the $100 \mathrm{~kg} \mathrm{~N}^{-1}$ treatment, the dose was divided into two and applied on July 16 (50\%) and August 16, 2019 (50\%). Samples were cut with scissors, using a square with an area of $0.25 \mathrm{~m}^{2}$. These samples were carried out in duplicate, to a minimum height of $0.10 \mathrm{~m}$, based on the premise that cutting below that height would reflect excessive grazing and, therefore, would be inadequate for the regrowth of plants.

The degree-days were determined according to Müller et al. (2009), and the basal temperature was $5{ }^{\circ} \mathrm{C}$ (Coblentz et al., 2018). The degree-days were determined using the following formula:

$$
D G=\frac{(\operatorname{Max} T-B T)^{2}}{[2(\operatorname{Max} T-\operatorname{Min} T)]}
$$

where:

\section{$D G=$ degree - days \\ MaxT=Maximum temperature \\ $B T=$ Basal temperatura \\ MinT=Minimum temperature}

Sampling took place on August 7 and 25,2019 . After the cutting, samples were predried in a forced circulation oven at $55{ }^{\circ} \mathrm{C}$ for $72 \mathrm{~h}$. A Willey mill with a $1 \mathrm{~mm}$ sieve was used for grinding. 
The chemical composition of the samples was evaluated using near-infrared spectroscopy (NIRS) with a FOSS 5000 transport module (Eden Prairie, MN, USA), at the ESALQLAB laboratory of the Escola Superior de Agricultura "Luiz de Queiroz" at the University de São Paulo, using the NIR calibrations (WinISI version 4.6.11, FOSS Analytical A / S, Denmark) obtained from the Dairy One Forage Laboratory (Ithaca, NY) to determine the concentrations of: dry matter (DM), total carbohydrates (TC), non-fibrous carbohydrates (NFC), soluble carbohydrates (SC), neutral detergent fiber (NDF), acid detergent fiber (ADF), lignin, crude protein $(\mathrm{CP})$, soluble protein (SP), neutral detergent insoluble protein (NDFIP), acid detergent insoluble protein (ADFIP), degradable protein $(D P)$, ether extract (EE), oleic fatty acid (AG C18: 1), linoleic fatty acid (AG C18: 2), linolenic fatty acid (AG C18: 3), digestible NDF with 24 $\mathrm{h}$ of incubation (NDF24h), digestible NDF with $30 \mathrm{~h}$ of incubation (NDF30h), digestible NDF with $48 \mathrm{~h}$ of incubation (NDF48h) and NDF degradation rate (Kd-NDF).

Using the results of the chemical composition, the yields per hectare of each nutrient in the pasture of Triticale BRS Saturno were calculated. Descriptive statistics of yields per hectare were determined, and a simple linear regression was performed using Minitab software, with a significance level of $5 \%$.

\section{Results and Discussion}

The record of meteorological conditions that occurred during the experiment (Table 1) compared to normal climatic conditions (1961-1990) allowed us to verify that the rainfall in 2019 caused a water deficit for the development of Triticale pastures, and the average temperature was $1{ }^{\circ} \mathrm{C}$ higher than average of climatological normals. The thermal sum up to the first cut was 610 degree days and between the first and second cut, which occurred 18 days apart, it was 210 degree days.

Meteorological conditions (temperature, rainfall, and light) are determining factors for pasture production (Bergamaschi \& Bergonci, 2017). In a review, Lee, Clark and Roche (2013) reported that milk production systems based on temperate pastures were more susceptible to interference from weather conditions, implying changes in the quantity and quality of forage available to animals. The lack of water tends to decrease the enzymatic activity of photosynthesis because of a reduction in the diffusion of $\mathrm{CO} 2$ in the environment and the closure of stomata. This corroborates the data of Pembleton et al. (2013), who studied levels of nitrogen fertilization in perennial ryegrass (Lolium perenne L.) in Australia and identified that the absence of water in the soil nullified the effect of nitrogen fertilizer topdressing, making it impossible for plants to use; there was a consequent reduction in dry matter production per hectare.

According to Bergamaschi and Bergonci (2017), under conditions of water deficit, there is an increase in the temperature of the leaf portion. This rise in temperature interferes with the physiological processes of the plant, such as increased photorespiration and allows protein denaturation to occur. Further studies are needed to identify the effect of temperature increases on the production of forage nutrients.

The production of dry matter $(\mathrm{P}=$ $0.012)$, total carbohydrates $(P=0.050)$, neutral detergent fiber $(P=0.013)$, and acid detergent 
fiber $(P=0.004)$ from Triticale pastures (Table 2) were significantly influenced by different nitrogen doses in topdressing. This supports the theories reported by Bergamaschi and Bergonci (2017) and Pembleton et al. (2013) which suggest that nitrogen application favors the production of nutrients in a linear way for each kilogram of nitrogen applied by topdressing, regardless of the level of water deficit. However, the production of nonfibrous carbohydrates, soluble carbohydrates, hemicellulose, and lignin was not influenced ( $P$ $>0.05$ ) by the treatments.

Table 2

Production of dry matter, fibrous and non-fibrous carbohydrates in Triticale BRS Saturno pasture

\begin{tabular}{|c|c|c|c|c|c|c|}
\hline \multirow{2}{*}{ Production } & \multicolumn{3}{|c|}{ Treatments (kg of $\left.\mathrm{N} \mathrm{ha}^{-1}\right)$} & \multirow{2}{*}{ LR } & \multirow{2}{*}{$\mathrm{R}^{2}$} & \multirow{2}{*}{ Prob } \\
\hline & 0 & 50 & 100 & & & \\
\hline Dry matter (kg ha-1) & 1,077 & 1,524 & $1,613,6$ & $\hat{\mathrm{Y}}=1,137.0+5.364^{\times} \mathrm{ND}$ & 35.08 & $=0.012$ \\
\hline Total carbohydrates $\left(\mathrm{kg} \mathrm{ha}^{-1}\right)$ & 785 & $1,026.1$ & $1,058.5$ & $\hat{Y}=820.0+2.732^{\times} \mathrm{ND}$ & 20.85 & $=0.050$ \\
\hline Non-fibrous carbohydrates (kg ha-1) & 261.8 & 218.6 & 251.7 & $\hat{Y}=244.0$ & -- & -- \\
\hline Soluble carbohydrates (kg ha-1) & 212.2 & 221.7 & 201.70 & $\hat{Y}=211.9$ & -- & -- \\
\hline Neutral detergent fiber $\left(\mathrm{kg} \mathrm{ha}^{-1}\right)$ & 523.5 & 807.5 & 806.8 & $\hat{Y}=571.0+2.833^{x} N D$ & 33.83 & $=0.013$ \\
\hline Acid detergent fiber (kg ha-1) & 296.8 & 445.7 & 481.7 & $\hat{Y}=315.6+1.849 \times N D$ & 44.52 & $=0.004$ \\
\hline Hemicellulose (kg ha-1) & 226.8 & 361.9 & 325.1 & $\hat{Y}=304.6$ & -- & -- \\
\hline Lignin $\left(\mathrm{kg} \mathrm{ha}^{-1}\right)$ & 29.08 & 40.38 & 33.89 & $\hat{Y}=34.45$ & -- & -- \\
\hline
\end{tabular}

LR = Linear regression; ND = Nitrogen doses.

Assessing the dry matter production of Triticale BRS 148 in a "Cfa" climate in the Central Depression of Rio Grande do Sul, Brazil, Meinerz et al. (2012) obtained a total production of 5,568 kilograms per hectare, with nitrogen fertilizer at a cover rate of $120 \mathrm{~kg}$ $\mathrm{ha}^{-1}$, applied in the form of urea in three equal doses. Fontaneli et al. (2009) carried out an experiment in the municipality of Passo Fundo, Rio Grande do Sul, Brazil, in a LATOSSOLO VERMELHO Distrófico típico soil type to evaluate three cultivars of Triticale (BRS 148, BRS 203, and EMBRAPA 53). They reported that, with only one cut when the plants reached $30 \mathrm{~cm}$ in height, dry matter yields of 718,828 , and 598 kg, respectively, were obtained (Fontaneli et al., 2009). The data from these studies show the great variation in dry matter production, demonstrating the need for further studies with Triticale, especially in dual-purpose conditions (pastures and grains). In the present study (Table 2), the production of dry matter per hectare increased $(P=$ 0.012) as the nitrogen levels in topdressing increased. However, the results were not exceptionally high, probably because of the low rainfall during the experiment.

Evaluating the effects of growth stages and the accumulation of degree days in Triticale for silage with application of $52 \mathrm{~kg}$ of nitrogen ha-1, Coblentz et al. (2018) determined the production of $1,203 \mathrm{~kg}$ of matter ha-1 drought in the vegetative stage. NDF production was 
$504 \mathrm{~kg} \mathrm{ha}^{-1}$, and ADF production was $276 \mathrm{~kg}$ ha-1. In the study by Fontaneli et al. (2009), under the same nitrogen dosage, the cultivars of Triticale BRS 148, BRS 203, and Embrapa 53 produced NDF amounts of 386,438 , and $322 \mathrm{~kg} \mathrm{ha}^{-1}$ and ADF amounts of 174; 213 and $135 \mathrm{~kg} \mathrm{ha}^{-1}$, respectively. The data from both studies showed values lower than or close to those found in the present study, since the interaction with the amount of nitrogen fertilizer applied, the methodology used, and the edaphoclimatic conditions of the places where the work was carried out can influence the plant's physiological response, interfering in its production cycle and form to reduce or extend the period of forage use.

The production of soluble carbohydrates remained around the average between doses, but it was higher than that reported by Coblentz et al. (2018), who calculated the production of $144.36 \mathrm{~kg} \mathrm{ha}^{-1}$ of water-soluble carbohydrates. Soluble carbohydrates stimulate the growth of the rumen microbiota that ferment non-fibrous carbohydrates (Russell, O'Connor, Fox, Van Soest, \& Sniffen, 1992).

In Table 3, it can be seen that the production of the different fractions of the nitrogenous constituents was significantly altered $(P<0.01)$ by the different doses of nitrogen in topdressing, and the production of degradable protein per hectare also varied $(P$ $<0.001$ ) with treatments. In their work, Coblentz et al. (2018) determined the production of 287 $\mathrm{kg}$ of crude protein. The production of insoluble protein in neutral detergent was similar to the values calculated in the present study, while the production of insoluble protein in acid detergent was higher than the values found in pastures with and without nitrogen. Working with winter pastures, Fontaneli et al. (2009) found lower crude protein production, that is, the Triticales BRS 148, BRS 203, and Embrapa 203 produced approximately 163, 200, and $138 \mathrm{~kg}$ of crude protein ha-1, respectively. The low amounts of insoluble protein in acid detergent fiber demonstrate that the nitrogenous constituents present in the pastures of Triticale BRS Saturno will not limit microbial growth, regardless of the category of dairy cattle (National Research Council [NRC], 2001) and beef cattle (NRC, 2016). According to Van Soest (1994), values below $7 \%$ of crude protein in the rumen can limit the fermentation of substrates. Therefore, the nitrogen available to the ruminal microbiota helps to explain the digestibility of NDF (Table 4). According to Sniffen, O'Connor, Van Soest, Fox and Russell (1992) and Bumbieris et al. (2011), synergy and synchrony are fundamental for animal performance. 
Table 3

Production of nitrogenous constituents in Triticale BRS Saturno pasture

\begin{tabular}{|c|c|c|c|c|c|c|}
\hline \multirow{2}{*}{ Production } & \multicolumn{3}{|c|}{ Treatments (kg of $\mathrm{N} \mathrm{ha}^{-1}$ ) } & \multirow{2}{*}{ LR } & \multirow{2}{*}{$\mathrm{R}^{2}$} & \multirow{2}{*}{ Prob } \\
\hline & 0 & 50 & 100 & & & \\
\hline Crude protein (kg ha-1) & 221.9 & 401.5 & 441.3 & $\hat{Y}=245.2+2.194^{\times} \mathrm{ND}$ & 59.50 & $<0.001$ \\
\hline Soluble protein $\left(\mathrm{kg} \mathrm{ha}^{-1}\right)$ & 86.5 & 168.6 & 161.08 & $\hat{Y}=101.5+0.7454^{\times} \mathrm{ND}$ & 42.77 & $=0.005$ \\
\hline $\begin{array}{l}\text { Neutral detergent insoluble } \\
\text { protein }\left(\mathrm{kg} \mathrm{ha}^{-1}\right)\end{array}$ & 60.69 & 113.2 & 119.60 & $\hat{Y}=68.38+0.5891 \times N D$ & 55.53 & $=0.001$ \\
\hline $\begin{array}{l}\text { Acid detergent insoluble } \\
\text { protein }\left(\mathrm{kg} \mathrm{ha}^{-1}\right)\end{array}$ & 5.215 & 27.90 & 32.22 & $\hat{\mathrm{Y}}=8.277+0.2700^{\times} \mathrm{ND}$ & 77.87 & $<0.001$ \\
\hline Degradable protein $\left(\mathrm{kg} \mathrm{ha}^{-1}\right)$ & 155.3 & 293.1 & 331.0 & $\hat{\mathrm{Y}}=172.0+1.757^{\times} \mathrm{ND}$ & 64.65 & $<0.001$ \\
\hline
\end{tabular}

$\mathrm{LR}=$ Linear regression; ND = Nitrogen doses.

Table 4

Neutral detergent fiber digestibility and degradability rate $(\% / h)$ of Triticale BRS Saturno pasture

\begin{tabular}{|c|c|c|c|c|c|c|}
\hline \multirow{2}{*}{ Variable } & \multicolumn{3}{|c|}{ Treatments (kg of N ha-1) } & \multirow{2}{*}{ LR } & \multirow{2}{*}{$\mathrm{R}^{2}$} & \multirow{2}{*}{ Prob } \\
\hline & 0 & 50 & 100 & & & \\
\hline Digestible NDF $24 \mathrm{~h}\left(\mathrm{~kg} \mathrm{ha}^{-1}\right)$ & 332.4 & 512.8 & 492.1 & $\hat{Y}=365.9+1.597^{\times} \mathrm{ND}$ & 26.96 & $=0.027$ \\
\hline Digestible NDF 30h (kg ha-1) & 384.8 & 589.5 & 572.8 & $\hat{\mathrm{Y}}=421.7+1.880^{\times} \mathrm{ND}$ & 28.43 & $=0.024$ \\
\hline Digestible NDF 48h (kg ha-1) & 405.7 & 605.6 & 593.0 & $\hat{\mathrm{Y}}=441.2+1.873^{\times} \mathrm{ND}$ & 27.18 & $=0.027$ \\
\hline $\mathrm{Kd}(\% / \mathrm{h})$ & 5.85 & 5.70 & 5.35 & $\hat{Y}=5.884-0.0004950^{x} N D$ & 94.18 & $<0.001$ \\
\hline
\end{tabular}

$K d=$ Degradability rate; $L R=$ Linear regression; ND = Nitrogen doses; NDF = Neutral detergent fiber .

The production of digestible NDF per hectare increased linearly with the topdressing nitrogen levels. It is important to emphasize that evaluation within $24 \mathrm{~h}$ is the most important, according to Van Soest (1994), since evaluations with incubation times greater than $24 \mathrm{~h}$ indicate the indigestibility of the fractions. Evaluating corn silages with different treatments, Velho et al. (2014) found that incubation times greater than 24 $h$ caused confusion in the interpretation of results. The digestible NDF production with $24 \mathrm{~h}$ of incubation in this study demonstrated that the Triticale BRS Saturno pasture had high nutritional value that stimulated animal production. The linear decrease in the NDF degradation rate can be explained by the formation dynamics of hemicelluloses and phenolic compounds present in lignins that are closely related to fibrous carbohydrates. Thus, the production of digestible NDF within $24 \mathrm{~h}$ was greater in the intermediate treatment (50 kg of $\mathrm{N} \mathrm{ha}^{-1}$ ), as it stimulated less cell wall deposition during the vegetative stage.

In the total production of ether extract (Table 5) and linoleic (C18: 2) and linolenic (C18: 3) fatty acids, there was a significant increase $(P<0.05)$ due to the addition of topdressing nitrogen fertilization, but it did not influence 
$(P>0.05)$ the production of oleic fatty acid (C18: 1). Recently, Tran et al. (2020) and Daley, Armentano, Kononoff and Hanigan (2020) presented the results of scientific studies carried out in the United States of America, aiming to detail the fatty acid composition of the foods offered to dairy cows since the partitioning of fibrous and non-fibrous carbohydrates and nitrogen constituents are already well determined through the Cornell Net Carbohydrate and Protein System (CNCPS), and their effects on animals and the products generated (meat and milk) are understood. However, it is still essential to better understand the effects of lipids.

\section{Table 5}

\section{Ether extract and fatty acid production in Triticale BRS Saturno pasture}

\begin{tabular}{cccccccc} 
Production & \multicolumn{9}{c}{ Treatments $\left(\mathrm{kg} \mathrm{of} \mathrm{N} \mathrm{ha}^{-1}\right)$} & LR & $\mathrm{R}^{2}$ & Prob \\
\cline { 2 - 5 } & 0 & 50 & 100 & & & \\
Ether extract $\left(\mathrm{kg} \mathrm{ha}^{-1}\right)$ & 44.7 & 81.5 & 87.9 & $\hat{\mathrm{Y}}=49.77+0.4324^{\times} \mathrm{ND}$ & 57.36 & $<0.001$ \\
C18:1 Oleico $\left(\mathrm{kg} \mathrm{ha}^{-1}\right)$ & 4.6 & 4.9 & 5.1 & $\hat{\mathrm{Y}}=4.9$ & -- & -- \\
C18:2 Linoleico $\left(\mathrm{kg} \mathrm{ha}^{-1}\right)$ & 8.4 & 11.1 & 12.0 & $\hat{\mathrm{Y}}=8.674+0.03676^{\times} \mathrm{ND}$ & 31.56 & $=0.017$ \\
C18:3 Linolenico $\left(\mathrm{kg} \mathrm{ha}^{-1}\right)$ & 12.3 & 17.1 & 18.5 & $\hat{\mathrm{Y}}=12.83+0.06272^{\times} \mathrm{ND}$ & 37.47 & $=0.009$
\end{tabular}

LR = Linear regression; ND = Nitrogen doses.

According to Sun, Plastow and Guan (2019), with the evolution of "feedomics" it is important to determine the amounts of all nutrients in the diet, since their interaction influences animal health, as well as the production of milk and its derivatives. Pastures have rarely been evaluated with regard to the fatty acid profile, but the results of the present study demonstrate that such studies are important, mainly to determine the links in diets between the relações -6 and $\omega-3$ relationships. Freitas et al. (2014), using legumes to improve native pasture in the Pampa Biome, found that steers finished exclusively on pastures showed a higher amount of $\omega-3$ in the meat, as well as a decreased ratio between $\omega-6 / \omega-3$.

\section{Conclusions}

The different doses of nitrogen fertilization in pasture cover of Triticale BRS Saturno alter the production of dry matter and other nutrients, which are important for the feeding and nutrition of ruminant animals.

\section{Acknowledgements}

We would like to thank the Financiadora de Estudos e Projetos (FINEP) of the Ministério da Ciência e Tecnologia (MCT) for the financial resources made available in the Public Call MCT/FINEP/CT-INFRA - CAMPI REGIONAIS - 01/2010, which allowed the Universidade Federal de Santa Maria - Campus of Palmeira das Missões to establish the Laboratório de Estudos sobre a Interface Planta-Animal. This 
study was financed in part by the Coordenação de Aperfeiçoamento de Pessoal de Nível Superior - Brasil (CAPES; Finance Code 001). We also thank the Fundo de Incentivo à Pesquisa da Universidade Federal de Santa Maria (FIPE - UFSM) for the grant awarded to Gustavo Veiverberg Antunes. We also thank the Fundação de Amparo à Pesquisa do Estado do Rio Grande do Sul (FAPERGS) for the grant awarded to Andiara Laíssa Bernardi. We also thank the Fundação de Amparo à Pesquisa e Inovação do Estado de Santa Catarina (FAPESC) for the grant awarded to Gadriéli Cristina Gheno. We also thank the Conselho Nacional de Desenvolvimento Científico e Tecnológico (CNPq) for the grant awarded to Gabriela Feiten Gabbi.

\section{References}

Alvares, C. A., Stape, J. L., Sentelhas, P. C., Gonçalves, J. L. M., \& Sparovek, G. (2013). Köppen's climate classification map for Brazil. Meteorologische Zeitschrift, 22(6), 711-728. doi: 10.1127/0941-2948/ 2013/0507

Ates, S., Cicek, H., Gultekin, I., Yigezu, Y. A., Keser, M., \& Filley, S. J. (2018). Bioeconomic analysis of dual-purpose management of winter cereals in high and low input production systems. Field Crops Research, 227, 56-66. doi: 10.1016/j.fcr. 2018.08.003

Bergamaschi, H., \& Bergonci, J. I. (2017). As plantas e o clima: princípios e aplicações. Guaíba, RS: Agrolivros.

Bortolini, P. C., Sandini, I., Carvalho, P. C. F., \& Moraes, A. (2004). Cereais de inverno submetidos ao corte no sistema de duplo propósito. Revista Brasileira de Zootecnia,
33(1), 45-50. doi: 10.1590/S1516-3598 2004000100007

Buccioni, A., Decandia, M., Minieri, S., Molle, G., \& Cabiddu, A. (2012). Lipid metabolism in the rumen: New insights on lipolysis and biohydrogenation with an emphasis on the role of endogenous plant factors. Animal Feed Science and Technology, 174(1), 1-25. doi: 10.1016/j. anifeedsci.2012.02.009

Bumbieris, V.H., Jr., Jobim, C.C., Emile, J.C., Rossi, R., Calixto, M., Jr., \& Branco, A. F. (2011). Degradabilidade ruminal e fracionamento de carboidratos e proteínas em silagens de triticale em cultivo singular ou em misturas com aveia e/ou leguminosas. Semina: Ciências Agrárias, 32(2), 759-770. doi: 10.5433/1679-0359.2011v32n2p759

Carvalho, P. C. F., Barro, R. S., Barth, A. Neto, Nunes, P. A. A., Moraes, A., Anghinoni, I., Borin, J. B. M. (2018). Integrating the pastoral components in agricultural systems. Revista Brasileira de Zootecnia, 47, e20170001. doi: 10.1590/rbz472017 0001

Coblentz, W. K., Akins, M. S., Kalscheur, K. F., Brink, G. E., \& Cavadini, J. S. (2018). Effects of growth stage and growing degree day accumulations on triticale forage: 1. Dry matter yield, nutritive value, and in vitro dry matter disappearance. Journal of Dairy Science, 101(10), 8965-8985. doi: 10.3168/jds.2018-14868

Daley, V. L., Armentano, L. E., Kononoff, P. J., \& Hanigan, M. D. (2020). Modeling fatty acids for dairy cattle: 1 . Models to predict total fatty acid concentration and fatty acid digestion of feedstuffs. Journal of Dairy Science, 103(8), 6982-6999. doi: 10.3168/ jds.2019-17407 
Fontaneli, R. S., Fontaneli, R. S., Santos, H. P., Nascimento, A., Minella Jr., E., \& Caierão, E. (2009). Rendimento e valor nutritivo de cereais de inverno de duplo propósito: forragem verde e silagem ou grãos. Revista Brasileira de Zootecnia, 38(11), 2116-2120. doi: 10.1590/S151635982009001100007

Freitas, A. K., Lobato, J. F. P., Cardoso, L. L., Tarouco, J. U., Vieira, R. M., Dillenburg, D. R., \& Castro, I. (2014). Nutritional composition of the meat of Hereford and Braford steers finished on pastures or in a feedlot in southern Brazil. Meat Science, 96(1), 353360. doi: 10.1016/j.meatsci.2013.07.021

Giunta, F., Cadeddu, F., Mureddu, F., Virdis, A., \& Motzo, R. (2020). Triticale cultivar mixtures: productivity, resource use, and resource use efficiency in a Mediterranean environment. European Journal of Agronomy, 115,126019. doi: 10.1016/j.eja. 2020.126019

Giunta, F., Motzo, R., Virdis, A., \& Cabigliera, A. (2017). Effects of forage removal on biomass and grain yield of intermediate and spring triticales. Field Crops Research, 200(1), 47-57. doi: 10.1016/j.fcr.2016.10. 002

Henz, E. L., Almeida, P.S.G., Velho, J.P., Nörnberg, J., Silva, L. D. F. da, Massaro, F. L., Jr., \& Guerra, G.L. (2016). Nitrogenfertilizationfor wheat growing in dual-purpose integrated system of agricultural production. Semina: Ciências Agrárias, 37(3), 1679-1688. doi: 10.5433/1679-0359.2016v37n3p1679

Hu, C., Sadras, V. O., Lu, G., Jin, X., Xu, J., Ye, Y.,... Zhang, S. (2019). Dual-purpose winter wheat: interactions between crop management, availability of nitrogen, and weather conditions. Field Crops Research, 241, 107579. doi: 10.1016/j.fcr. 2019.107579

Lanzas, C., Sniffen, C. J., Seo, S., Tedeschi, L. O., \& Fox, D. G. (2007). A revised CNCPS feed carbohydrate fractionation scheme for formulating rations for ruminants. Animal Feed Science and Technology, 136(3), 167-190. doi: 10.1016/j.anifeedsci. 2006.08.025

Lee, J. M., Clark, A. J., \& Roche, J. R. (2013). Climate-change effects and adaptation options for temperate pasture-based dairy farming systems: a review. Grass and Forage Science, 68(4), 485-503. doi: 10.11 11/gfs.12039

Liu, N., Pustjens, A. M., Erasmus, S. W., Yang, Y., Hettinga, K., \& Van Ruth, S. M. (2020). Dairy farming system markers: the correlation of forage and milk fatty acid profiles from organic, pasture, and conventional systems in the Netherlands. Food Chemistry, 314, 126-153. doi: 10.1016/j. foodchem. 2019.126153

Lobato, J. F. P., Freitas, A. K., Devincenzi, T., Cardoso, L. L., Tarouco, J. U., Vieira, R. M., Castro, I. (2014). Brazilian beef produced on pastures: sustainable and healthy. Meat Science, 98(3), 336-345. doi: 10.1016/j. meatsci.2014.06.022

Meinerz, G. R., Olivo, C. J., Fontaneli, R. S., Agnolin, C. A., Horst, T., \& Bem, C. M. (2012). Produtividade de cereais de inverno de duplo propósito na depressão central do Rio Grande do Sul. Revista Brasileira de Zootecnia, 41(4), 873-882. doi: 10.1590/ S1516-35982012000400007 
Müller, L., Manfron, P. A., Medeiros, S. L. P., Streck, N. A., Mittelmman, A., Dourado Neto, D., Morais, K. P. (2009). Temperatura base inferior e estacionalidade de produção de genótipos diplóides e tetraplóides de azevém. Ciência Rural, 39(5), 1343-1348. doi: 10.1590/s0103-84 782009005000098

National Research Council (2001). Nutrient requirements of dairy cattle (7nd ed.). Washington, DC: National Academies Press.

National Research Council (2016). Nutrient requirements of beef Cattle (7nd ed.). Washington, DC: National Academies Press.

Oliveira, T. E., Freitas, D. S., Gianezini, M., Ruviaro, C. F., Zago, D., Mércio, T. Z., Barcellos, J. O. J. (2017). Agricultural land use change in the Brazilian Pampa Biome: the reduction of natural grasslands. Land Use Policy, 63, 394-400. doi: 10.1016/j. landusepol.2017.02.010

Pembleton, K. G., Rawnsley, R. P., \& Burkitt, L. L. (2013). Environmental influences on optimum nitrogen fertilizer rates for temperate dairy pastures. European Journal of Agronomy, 45, 132-141. doi: 10.1016/ j.eja.2012.09.006

Quatrin, M. P., Olivo, C. J., Bratz, V. F., Alessio, V., Santos, F. T., \& Aguirre, P. F. (2017). Nutritional value of dual-purpose wheat genotype pastures under grazing by dairy cows. Acta Scientiarum. Animal Science, 39(3), 303-308. doi: 10.4025/ actascianimsci.v39i3.34420

Russell, J. B., O'Connor, J. D., Fox, D. G., Van Soest, P. J., \& Sniffen, C. J. (1992). A net carbohydrate and protein system for evaluating cattle diets: I. Ruminal fermentation. Journal of Animal Science, 70(11), 3551-3561. doi: 10.2527/1992.70113551x

Santos, H. P., Fontaneli, R. S., Caierão, E., Spera, S. T., \& Vargas, L. (2011). Desempenho agronômico de trigo cultivado para grãos e duplo propósito em sistemas de integração lavoura-pecuária. Pesquisa Agropecuária Brasileira, 46(10), 12061213. doi: 10.1590/S0100-204X2011001 000013

Savian, J. V., Schons, R. M. T., Marchi, D. E., Freitas, T. S., Silva, G. F. S. Neto,, Mezzalira, J. C., Carvalho, P. C. F. (2018). Rotatinuous stocking: A grazing management innovation that has high potential to mitigate methane emissions by sheep. Journal of Cleaner Production, 186, 602608. doi: 10.1016/j. jclepro.2018.03.162

Skinner, R. H. (2013). Nitrogen fertilization affects pasture photosynthesis, respiration, and ecosystem carbon content. Agriculture, Ecosystems, and Environment, 172, 35-41. doi: 10.1016/j. agee.2013.04.005

Sniffen, C. J., O'Connor, J. D., Van Soest, P. J., Fox, D. G., \& Russell, J. B. (1992). A net carbohydrate and protein system for evaluating cattle diets: II. Carbohydrate and protein availability. Journal of Animal Science, 70(11), 3562-3577. doi: $10.2527 / 1992.70113562 x$

Sprague, S. J., Kirkegaard, J. A., Bell, L.W., Seymour, M., Graham, J., \& Ryan, M. (2018). Dual-purpose cereals offer increased productivity across diverse regions of Australia's high rainfall zone. Field Crops Research, 227, 119-131. doi: 10.1016/j. fcr.2018.08.008 
Sprague, S. J., Kirkegaard, J. A., Graham, J. M., Dove, H., \& Kelman, W. M. (2014). Crop and livestock production for dual-purpose winter canola (Brassica napus) in the highrainfall zone of south-eastern Australia. Field Crops Research, 156, 30-39. doi: 10. 1016/j.fcr.2013.10.010

Streck, E. V., Kämpf, N., Dalmolin, R. S. D., Klamt, E., Nascimento, P. C., Giasson, E., \& Pinto, L. F. S. (2018). Solos do Rio Grande do Sul (3a ed.). Porto Alegre, RS: UFRGS; EMATER/ RS-ASCAR.

Sun, H. Z., Plastow, G., \& Guan, L. L. (2019). Invited review: advances and challenges in the application of feedomics to improve dairy cow production and health. Journal of Dairy Science, 102(7), 5853-5870. doi: 10.3168/jds.2018-16126

Thornley, J. M., \& France, J. (2004). Mathematical models in agriculture: quantitative methods for the plant, animal, and ecological sciences (2nd ed.). London, UK: Oxford University Press.

Tian, L. H., Bell, L. W., Shen, Y. Y., \& Whish, P. M. (2012). Dual-purpose use of winter wheat in western China: cutting time and nitrogen application effects on phenology, forage production, and grain yield. Crop \& Pasture Science, 63(6), 520-528. doi: 10. 1071/CP12101
Tran, H., Schlageter-Tello, A., Caprez, A., Miller, P. S., Hall, M. B., Weiss, W. P., \& Kononoff, P. J. (2020). Development of feed composition tables using a statistical screening procedure. Journal of Dairy Science, 103(4), 3786-3803. doi: 10.3168/ jds.2019-16702

Tylutki, T. P., Fox, D. G., Durbal, V. M., Tedeschi, L. O., Russell, J. B., Van Amburgh, M. E.,... Pell, A. N. (2008). Cornell net carbohydrate and protein system: a model for precision feeding of dairy cattle. Animal Feed Science and Technology, 143(1), 174-202. doi: 10.1016/j.anifeedsci.2007.05.010

Van Soest, P. J. (1994). Nutritional ecology of ruminants. Ithaca, NY: Cornell University Press.

Velho, J. P., Mühlbach, P. R. F., Genro, T. C. M., Barcellos, J. O. J., Braccini, J., Neto, \& Silva, R. S. M. (2014). Modelos matemáticos para ajuste da produção de gases in vitro em diferentes tempos de incubação e cinética ruminal de silagens de milho. Semina: CiênciasAgrárias, 35(4), 2531-2540.doi:10. 5433/1679-0359.2014v35n4Suplp2531

Zaka, S., Frak, E., Julier, B., Gastal, F., \& Louarn, G. (2016). Intraspecific variation in thermal acclimation of photosynthesis across a range of temperatures in a perennial crop. AoB Plants, 8(1), plw035. doi: 10.1093/ aobpla/plw035 
